\title{
Has the ECB's Monetary Policy Prompted Companies to Invest, or Pay Dividends?
}

\author{
Lior Cohen ${ }^{\mathrm{a}}$, Marta Gómez-Puig ${ }^{\mathrm{b}}$ and Simón Sosvilla-Rivero ${ }^{\mathrm{c}}$
}

\begin{abstract}
This paper focuses on the influence of the European Central Bank's (ECB) monetary policies on nonfinancial firms. It sheds light on non-financial firms' decisions regarding leverage, and on how the ECB's conventional and unconventional policies may have affected them. The paper also examines how these policies influenced non-financial firms' decisions on capital allocation - primarily capital spending and shareholder distribution (for example, dividends and share repurchases). We use an exhaustive and unique dataset comprised of income statements and balance sheets of leading non-financial firms operating in the European Economic and Monetary Union (EMU). The main results suggest that ECB's monetary policies have encouraged firms to raise their debt burden, especially after the global recession of 2008. Finally, the ECB's policies, especially after 2011, also seem to have led non-financial firms to allocate more resources not just to capital spending but to shareholder distribution as well.
\end{abstract}

Keywords: ECB's monetary policy, capital structure, leverage, quantitative easing, capital expenditure, dividend's policy, shareholder yield.

JEL Classification codes: E52; E58; G31; G32.

\footnotetext{
${ }^{a}$ Department of Economics. Universidad de Barcelona. Email: lior@tradingnrg.com

${ }^{\mathrm{b}}$ Department of Economics and Riskcenter, Universidad de Barcelona. Email: marta.gomezpuig@ub.edu

${ }^{\mathrm{c}}$ Complutense Institute for Economic Analysis, Universidad Complutense de Madrid. Email: sosvilla@ccee.ucm.es
} 


\section{Introduction}

In recent years, one of the main problems facing developed countries has been the combination of slow economic growth and lack of inflation in an environment of zero lower bound on interest rates. Summers (2013) brought back the term "secular stagnation" - first coined by Hansen (1939) - to describe the economic environment in the United States since the 2008-2009 Great Recession. This term refers to a situation in which central banks cannot cut interest rates enough to boost investment and consumption. Indeed, the situation where a central bank is hitting the zero-lower bound is known as a "liquidity trap" and has fostered a wide literature that examines the effectivity of different fiscal and monetary policies (among them, the central bank's extraordinary monetary measures) to boost economic activity. See, for example, Krugman (1998), Bernanke and Reinhart (2004) and Krugman and Eggertsson (2012), to name a few.

On the other side of the Atlantic, the European Economic and Monetary Union (EMU) countries - which, unlike the US, are not part of a fiscal union, but only of a monetary one - faced a similar plight. Therefore, the responsibility of the European Central Bank (ECB) with regard to stimulating the euro area economy has been higher than that of the Federal Reserve and has led to the creation of a full set of different conventional and unconventional monetary policies. Summing up, in 2011-2012, after the worst years of the European sovereign debt crisis, the ECB tried to boost liquidity in financial markets by introducing the Securities Markets Program (SMP) - first announced in May 2010 whose objective was to inject funds into specific market segments that were suffering from insufficient liquidity and depth ${ }^{1}$. The SMP, unlike a quantitative easing program, only injected funds to small and less liquid markets that were engulfed with high-risk premium. On July 26, 2012, Mario Draghi promised to do "whatever it takes" to preserve the euro, with the aim of rekindling economic growth in the EMU. Since then, the ECB has introduced several (both conventional and unconventional) measures for stimulating monetary policy. Some of them include slashing interest rates (including cutting its cash rate to zero and the deposit rate to $-0.4 \%$ by March 2016), implementing both the longerterm refinancing operations (LTRO) and targeted longer-term refinancing operations (TLTRO), and introducing quantitative easing (QE) programs. The main QE programs introduced include the public sector purchase program (PSPP), the asset-backed securities purchase program (ABSPP), a covered bond purchase program (CBPP3), and the corporate sector purchase program (CSPP). As of January 2018, the PSPP was the largest program among all the assets purchase programs the ECB had implemented with over 1.9

\footnotetext{
${ }^{1}$ This program included buying sovereign bonds from five distressed EMU countries: Italy, Ireland, Spain, Portugal, and Greece. In November 2011, the ECB also launched the CBPP 2, which extended CBPP1, aiming to purchase additional covered bonds. After the arrival of Draghi, however, these programs were phased out - the SMP purchases ended in February 2012 and the CBPP ended in October 2012.
} 
trillion euros in holdings, and it accounted for over $82 \%$ of the total asset purchase programs.

In this context, this paper aims to examine whether ECB's conventional and unconventional monetary policies in times of crisis influenced non-financial firms' decisions. Specifically, it focuses on three critical issues: leverage, investments, and shareholder distribution. The contribution of this paper to the existing literature is twofold. First, it examines how ECB monetary policies in times of crisis have affected non-financial firms' decisions on leverage. Second, it analyzes how those policies have influenced non-financial firms' decisions on capital allocation - primarily capital spending and shareholder distribution (which comprises dividends and share buybacks). To the best of our knowledge, this is the first paper to delve so deeply into the study of the effects of the ECB's policies on non-financial firms. To this end, we use an exhaustive and unique dataset comprised of income statements and balance sheets of the leading nonfinancial firms that operate in EMU countries.

The main results suggest that the ECB's conventional and unconventional policies encouraged firms to raise their debt burden, especially after the global recession of 2008. Moreover, the ECB's monetary policies - mainly after 2011 in the wake of the European economic crisis and with the appointment of Mario Draghi as president - also seem to have led non-financial firms to allocate more resources not only to capital spending but also to shareholder distribution.

The rest of the paper is organized as follows. Section 2 reviews the literature on the effects of the ECB's monetary policies on non-financial firms. Section 3 presents the analytical framework. Section 4 describes the data used in the paper. Section 5 explains the econometric methodology and Section 6 reports the empirical results. Finally, Section 7 presents the concluding remarks and suggests some possible policy implications.

\section{The effects of the ECB's monetary policies on non-financial firms}

An extensive literature has studied the impact of ECB's policies since 2011 from different perspectives and using different methodologies; however, only a few papers have focused on the effects of these policies on non-financial corporations, despite the crucial role that the latter play in the economy ${ }^{2}$. Lenza et al. (2010) and Giannone et al. (2012) focus on the impact of the ECB's monetary policy on macroeconomic variables by applying VAR methods, while Gambacorta et al. (2014) examine the relations between the ECB's balance sheet and macroeconomic conditions. They estimate a panel of eight advanced economies and show that an unexpected rise in a central bank's balance sheet - mostly via QE programs - would raise liquidity (supply side), especially in countries where

\footnotetext{
${ }^{2}$ According to Eurostat, non-financial firms account for nearly 58\% of the total gross added value in the Euro Area and $55 \%$ of Euro Area's gross fixed capital formation (2002-2017 average).
} 
central banks are already hitting the zero-lower bound and under the prevailing conditions following the global economic crisis of 2008.

Indeed, only a few papers have attempted to show the link between non-financial corporations' investments in the EMU and the ECB's monetary policy. Darracq-Paries and De Santis (2015), who look at the effects of the 3-year long-term refinancing operations (LTROs) by considering them as a credit supply shock, show that LTROs have helped to increase the growth rate of real GDP and to raise the prospects of loan provisions for non-financial firms. Meanwhile, according to Ferrando et al. (2015) small and medium enterprises (which are more reliant on local bank credit) are hit harder by the euro area's credit crisis than large companies that are able to seek funding abroad. This result is more evident in the stressed countries (Spain, Italy, Greece, Portugal, and Ireland) than in the rest of the EMU countries.

Therefore, the existing literature that has already focused on the effects of ECB's unconventional monetary policy on non-financial corporations is not only scarce, but has not focused on how the different types of policy measures affected companies' decisions on capital structure and capital allocation. This paper will try to fill this gap.

\section{Analytical framework}

In order to analyze the possible effects of the ECB's monetary policies on non-financial firms' decisions, in this section, we will first review the literature on firms' optimal choice of capital and then examine how interest rates could influence their decisions to allocate capital between investments and profit distribution - via dividends and buybacks, or a combination of the two.

\subsection{Capital structure}

One of the first studies on firms' optimal choice of capital structure is the seminal paper by Modigliani and Miller (1958) who proposed what is known as the "leverage theorem". According to this theorem, in a context of asymmetric information between companies and investors, a firm determines its leverage ratio based on the capital cost and access to finance. However, since then many other theories have been proposed [Myers (1984), Kraus and Litzenberger (1973) or Merton (1974), to name a few]. Myers (1984) frame a company's choice under the "pecking order" theory which holds that firms prefer internal funds such as retained earnings to external financing, and debt to equity. Kraus and Litzenberger (1973) offer a competing view (the "trade-off" theory) which assumes that every company achieves an optimal capital structure (a "debt target") at some point in time and trades off tax advantages from debt against refinancing cost risk. Other authors consider market conditions - including interest rates - as a variable that might influence companies' decisions on their capital structure. Merton (1974), for example, examines from a theoretical perspective how changes in macroeconomic conditions influence 
companies on matters such as debt, while Barry et al. (2008) examine this subject, albeit empirically.

The above-mentioned theories have different implications, not only regarding the reasons underlying the company's decision to issue more debt but also with regard to the effects that interest rate changes have on that decision. Although there is no consensus on the effect that interest rate changes have on capital structure decisions, in this paper we do not aim to explore the accuracy of those models. Our objective is to use them as a background to build up an econometric framework to examine how those changes may influence firms' leverage decisions.

\subsection{Capital spending, dividends, and buybacks}

One of the ECB's goals in implementing its extraordinary monetary policies was to boost investment. The underlying logic (a negative correlation between investments and interest rates) is prominent in a simple Keynesian IS-LM model where interest rate and its coefficient of interest sensitivity determine investment:

$$
I=\bar{I}+d r
$$

In the above equation, $d>0$ stands for the coefficient of interest sensitivity; under normal economic conditions, falling interest rates should lead to higher investments and lift the aggregate demand. This relationship has mainly been examined in the literature from an empirical perspective, and its evolution in EMU countries from 1999 until present is shown in Figure 1. This figure shows that it is not clear-cut in the euro area since it only suggests a limited relationship between investments and yields (the correlation over the period is not significant, although the fall in interest rates since 2014 coincided with a steady rise in investment in EMU countries).

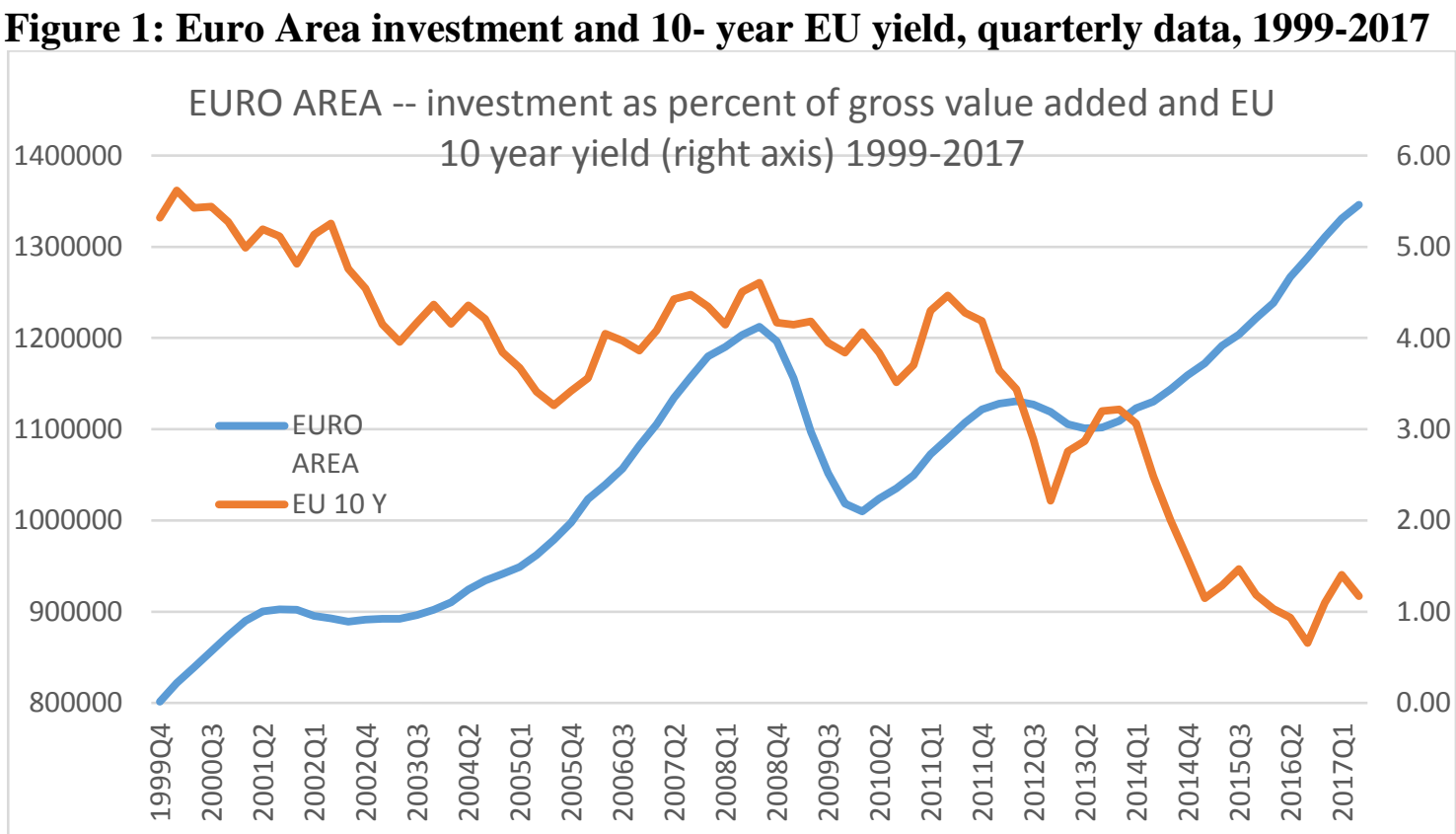

Source: Eurostat and European central bank data warehouse 
Nonetheless, the aim of this paper goes beyond this relationship, since the goal is to analyze the effect of interest rates not only on investments but also on dividends and buybacks. To the best of our knowledge, this is the first paper to examine how companies change their capital allocation between investments, buybacks, and dividends due to changes in interest rates. Below we present a simple analytical framework for understanding those relationships and the underlying assumptions behind them.

Let us consider that a company, which has already taken on a debt obligation, needs to decide how to allocate its resources. Specifically, consider a company that needs to evaluate how much to invest in a particular project - noted as $I$ - versus how much it should allocate to returning capital to shareholders - in the form of dividends or buybacks and noted as $V$-over a timeframe of two periods:

$$
Z_{i}=\frac{\pi(I)}{1+r}+\rho V
$$

$Z_{i}$ is the added value to the company's stock price, which the firm aims to maximize.

The firm has a budget constraint given by:

$$
1=\mathrm{I}+V
$$

This constraint means that the company has to divert all its resources towards an investment $I$ in a particular project or towards paying its shareholders via dividends or buybacks - noted as $V$ - or a combination of both (we are assuming that there are no other alternatives, for example, keeping the capital in cash).

The investment $I$ will yield in the first period a profit of $\pi(I)$ - a convex, continuous function of $I$ (let us assume that the company can allocate any portion it desires towards a particular project). This profit will need to be discounted with $(1+r)$ where $r$ stands for the company's cost of debt. For simplicity, we assume that $r$ is the prevailing market interest rate (in other words, the company's risk premium over the market is zero). Conversely, the company can allocate $V$ towards shareholders via dividends or buybacks. This shareholder distribution has a positive and constant return $\rho$. We then consider that profit distribution creates value for its shareholders because of its signalling mechanism about the positive prospects of the company's future returns - especially if the company's management considers its value to be underestimated ${ }^{3}$. This positive correlation could be explained by agency costs, information asymmetries, and market irrationality (Fairchild, 2006). It is worth noting that while the empirical research has also shown a positive relationship between buybacks and stock prices (Gup and Nam, 2001), with regard to the relation between dividends and firm valuation (Black and Scholes, 1974), the empirical

\footnotetext{
${ }^{3}$ Dividends tend to be "stickier" since, even if market conditions are not good, companies are likely to keep them so as not to alarm investors. Conversely, when companies face a transitory gain, they tend to distribute their windfall through buybacks rather than raise dividends and thus lift expectations about future dividends. This could explain the rise in buybacks in recent years, mainly, although not solely, in the United States.
} 
research is not conclusive. Using an international comparison, Denis and Osobov (2008) find scarce empirical evidence for a signalling effect for dividend-paying companies, Bernhardt et al. (2005) call into question the validity of signalling theories for dividends and Hussainey et al. (2011) support the positive relationship between dividends and share prices. In any case, for our model, we consider share buybacks and their more established positive relation with firm's value to justify a company's decision to allocate capital towards them instead of investing. In the econometric estimation, however, we use a broader term: "shareholder yield", which includes dividends, buybacks and deleveraging. With these methods, firms can return value to investors as a signalling mechanism.

Given these assumptions, we can solve the firm's maximization problem to establish how a company distributes its capital in time zero between $V$ and $I$, based on prevailing market interest rates. The Lagrangian equation is:

$$
\mathcal{L}=\frac{\pi(I)}{1+r}+\rho V+\lambda(\mathrm{I}+V-1)
$$

The First order condition (FOC) for the investment is:

$$
\pi^{\prime}(I)=-\lambda(1+r)
$$

while the FOC for the shareholder distribution is:

$$
-\rho=\lambda
$$

These two FOCs, before accounting for the $\lambda$ budget constraint, lead to:

$$
\frac{\pi^{\prime}(I)}{(1+r)}=\rho
$$

The solution shows that a company assesses a project based on two parameters: $\rho$ the company's return to shareholders, and $r$. Therefore, a company divides its resources between investments and shareholder distribution until the discounted marginal return on a given project is equal to the added value that a dividend or buyback has on a company's stock price. This is the framework that might help us to understand how monetary policy changes could impact non-financial firms' decisions on capital expenditure and shareholder yield ${ }^{4}$.

\footnotetext{
${ }^{4}$ To examine how these relationships work, we run simulations under different assumptions and investment functions. The results of these simulations suggest that under the baseline parameters, as $r$ falls, companies tend to allocate more capital towards investment rather than on shareholders' returns. However, as $\rho$ rises and interest rates fall, the tradeoff between investment and shareholder distribution tends to flatten. In other words, if the added value to shareholder is high enough mainly in a low interest rate environment, a further fall in the interest rate will not encourage firms to allocate more resources to investments rather than to shareholder distribution. Conversely, if $\rho$ is low, investment allocation is more likely to crowd out shareholder distribution as interest rates decline.
} 


\section{Data}

Data have been gathered from companies' financials provided by Bloomberg. We focus on non-financial firms listed in the leading stock exchanges from the four largest economies in the EMU: Germany (DAX), France (CAC40) Spain (IBEX35), and Italy (FTSE MIB $)^{5}$. Specifically, we gather quarterly data from a total of 62 non-financial firms (banks and insurance companies are excluded) registering a market capitalization of 2 trillion euros at the beginning of 2017 (which represents nearly a third of the total market capitalization of non-financial firms in the four leading stock exchanges). Therefore, our analysis focuses on large-cap companies since, although their number is not high, they represent a sizable portion of the market value of publicly traded non-financial firms in the EMU.

For our analysis, we use three main dependent variables: "CapEx-to-sales", "Debt-toequity" and "Shareholder yield" which capture capital spending, leverage, and capital distribution to shareholders respectively. Figures 2 and 3 show the high correlation between the first two variables' behaviour in the 62 companies included in the sample and in the four largest economies in the EMU (Germany, France, Spain and Italy) while a detailed description of them, together with the rest of the variables used in our analysis, is presented in Appendix A.

\section{Figure 2: Capital formation in selected EMU countries and capital spending of} firms in the sample, 2001-2016

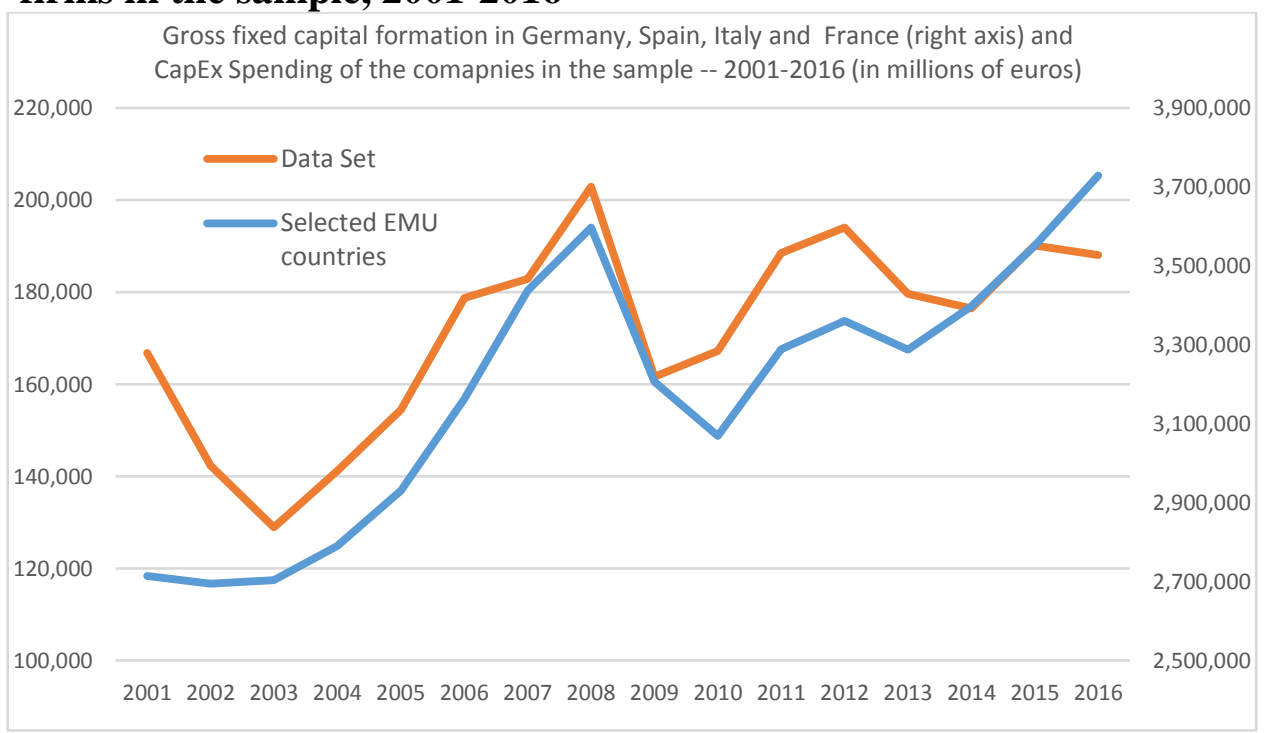

Source: Bloomberg, Eurostat and authors' calculations.

\footnotetext{
${ }^{5}$ A good representation for the entire EMU, since their aggregate GDP accounts for roughly 75\% of EMU's GDP in 2017

${ }^{6}$ Because of data restrictions, we use the total amount that a company returns to its shareholders by distributing dividends, repurchase shares or paying back debt as a proxy of the "shareholder yield".
} 
Figure 3: Private debt in selected EMU countries and total debt of firms in the sample, 2001-2016

Debt of Private Sector in Spain, Germany, Italy and France and Total Debt in the Data Set (right axis) in millions of Euros

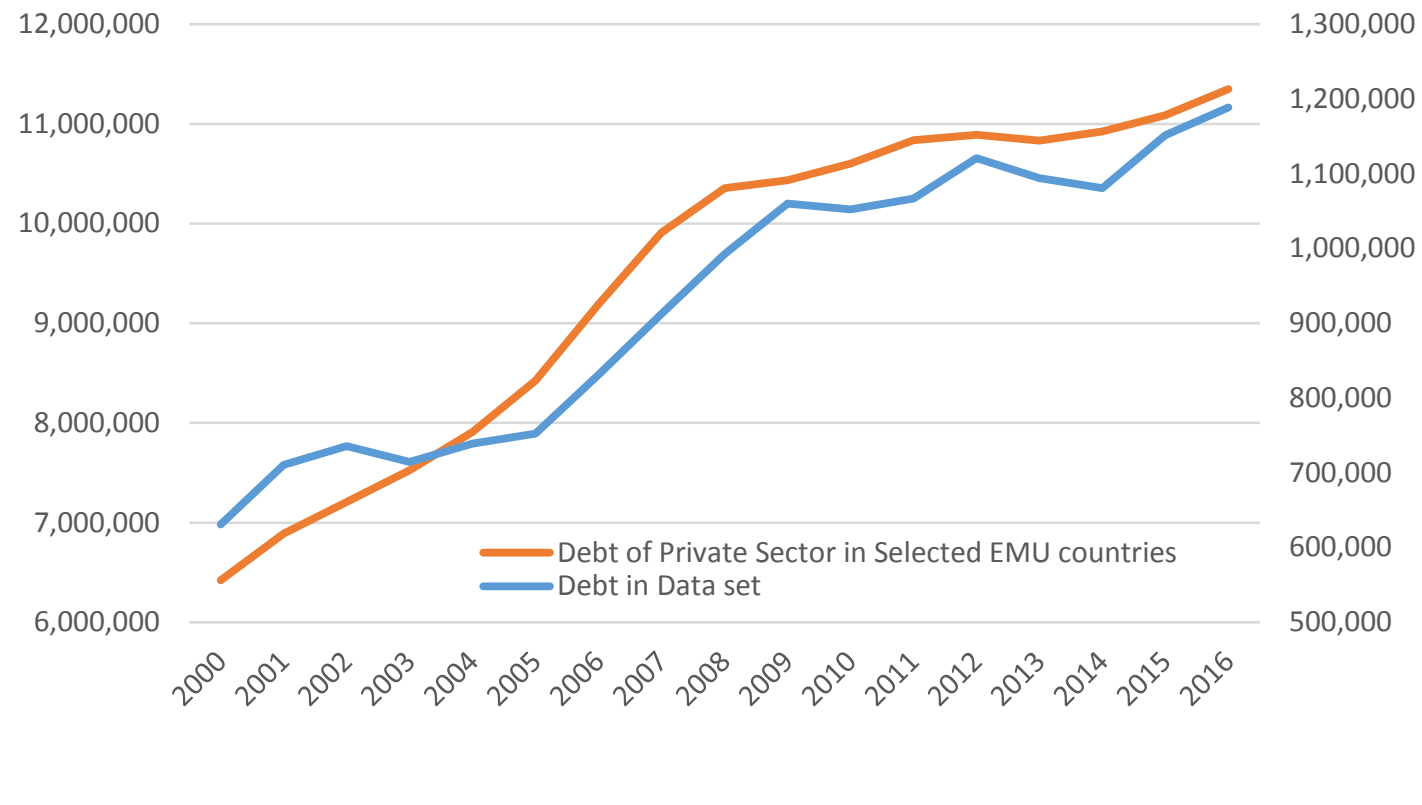

Source: Bloomberg, Eurostat and authors' calculations.

As for the independent variables that gauge monetary policies, we use changes to the ECB's assets and the 3-month Euribor interest rate. The ECB's assets are used because they show the different policy measures the ECB has employed over the years with regard to changes to its balance sheet. This variable does not distinguish the different policy schemes such as LTRO, TLTRO, PSPP, ABSPP, CBPP3, and CSPP. These programs have different targets, starting points and budgets, and some have even wound down in recent years. However, all these policies aim to boost liquidity and reduce borrowing costs. Moreover, since late 2014 the majority of the growth in the ECB's assets is attributed to the PSPP. Therefore, we choose the changes to the ECB assets to show how these conventional and unconventional policies, without distinction, affect companies' decisions. We then use the 3-month Euribor as a proxy of the ECB's direct impact on interest rates. We use this variable rather than the ECB's deposit rate because it has a more direct connection to the interest rates faced by companies, and these two variables are highly correlated.

To produce a data matrix without missing values, we apply two complementary procedures: the technique of multiple imputation developed by King et al. (2001) (which permits the approximation of missing data and allows us to obtain better estimates) and the simultaneous nearest-neighbour predictors proposed by Fernández-Rodríguez et al. (1999) (which infers omitted values from patterns detected in other simultaneous time series). 


\section{Econometric Estimation}

Based on the theoretical framework laid out in Section 4, we estimate the econometric models for examining the role of monetary policy in determining firms' capital spending, leverage and shareholder payouts. Our panel data analysis relies on Blundell and Roulet (2013) who looked at 4,000 global companies and examined the impact of low-interest rates - the direct result of the monetary policies of central banks including the Federal Reserve, the ECB and Bank of Japan in recent years - on their investments. They conclude that, since capital spending depends on the cost of equity and uncertainty, lowinterest rates and tax benefits incentivize long-term investment (because debt finance is cheap, companies have an incentive to borrow and carry out buybacks -also known as de-equitation).

\subsection{Leverage}

Two of the models most widely used in the literature to analyze the way a company decides on its capital structure are the tradeoff model of Kraus and Litzenberger (1973) and the pecking order model of Myers (1984). In the first model, a company raises its debt burden until it reaches a specific debt ratio target, and in the second, a company will first exhaust its internal funds (available cash) before raising funds from debt and equity. However, neither model analyzes the relationship between interest rates and the company's decisions on debt as described in Section 3.1; nor do they examine the role of macroeconomic or monetary policy factors (such as QE programs) on the capital structure of firms. Therefore, following Kühnhausen and Stiber $(2014)^{7}$, in our model, we incorporate external variables that might influence a company's decision on its debt-toequity ratio $\left(L_{i, t}\right.$ is the dependent variable in the model, which measures the company's debt burden or leverage):

$$
L_{i, t}=\alpha_{i, t}+\beta_{1} * X_{i, t-1}+\beta_{2} * Y_{t-1}+\beta_{3} * Z_{t-1}+\varepsilon_{i, t}
$$

As equation (7) shows, our model includes three prime independent variables. The first ( $X$ vector) corresponds to microeconomic variables that are attributed to each company, and is also related to the tradeoff and pecking order models. The second ( $Y$ vector) comprises macroeconomic variables that may proxy the changes in the economy. Finally, the third ( $Z$ vector) includes variables which are directly or indirectly related to the ECB's monetary policy and proxy supply-side developments ${ }^{8}$.

For our purposes, the monetary policy variables ( $Z$ vector) are the most important. They include the ECB's asset levels - a proxy for the ECB's asset purchase programs and loans

\footnotetext{
${ }^{7}$ Their model is based on Rajan and Zingales (1995) and includes five macroeconomic factors: GDP per capita, the growth rate of GDP (in constant local currency), inflation rate, interest rate, and tax rate.

${ }^{8}$ All independent variables, except WACC, lag the dependent variable by one period.
} 
- and changes in the 3-month Euribor interest rate. Since the ECB added more funds to the economy and brought down interest rates to encourage companies to take on more loans, we should expect a negative correlation between companies' leverage and interest rates and a positive correlation with the changes in the ECB's assets. Regarding the microeconomic variables ( $X$ vector), three variables are included in the model: profitability (EBITDA-to-sales), growth in profits (growth in earnings per share or EPS) and WACC. We include the variables profitability and growth in profits since they play an important role in determining the leverage of a company, as both Myers (1984) and Kraus and Litzenberger (1973) ${ }^{9}$ report. Additionally, the cost of capital (estimated by the Weighted Average Cost of Capital (WACC)) is a critical variable in this kind of model, and a negative relationship is to be expected between it and the leverage ratio. Finally, as regards the macroeconomic variables ( $Y$ vector), we have included the average inflation rate in the EMU because, since inflation depreciates the debt value in real terms, we should expect a positive relationship between this variable and leverage.

\subsection{Capital spending and shareholder's yield}

To analyze the relationship between ECB's monetary policy and the developments of capital spending and shareholder yields, we have adjusted the model described by Blundell and Roulet (2013), who conducted a panel data analysis and estimated two regressions (one for capital spending per sales and another for dividends and buybacks per sales). Therefore, we have also estimated two equations (an investment equation (8) and a shareholder yield equation (9)), but have adjusted their model by including variables that show how monetary policy affects capital expenditure and dividends/buybacks:

$$
\begin{gathered}
C_{i, t}=\alpha_{i, t}+\beta_{1} * i_{t-1}+\beta_{2} * E C B_{t-1}+\beta_{3} * S_{t-1}+\beta_{4} * P_{t-1}+\beta_{5} * E_{i, t-1}+\beta_{6} * k_{i, t-1}+\varepsilon_{i, t} \\
y_{i, t}=\gamma_{i, t}+\beta_{7} * i_{t-1}+\beta_{8} * E C B_{t-1}+\beta_{9} * E_{i, t-1}+\beta_{10} * k_{i, t-1}+\vartheta_{i, t}
\end{gathered}
$$

In equation (8), the dependent variable is the company's capital spending divided by sales $\left(c_{i, t}\right)$. The regression also includes the two main ECB policy variables - the cost of debt ( $i_{t-1}$ which is proxied by 3-months Euribor rate) and the changes in the ECB's assets $\left(E C B_{t-1}\right)$ - plus another four independent variables: the cost of capital $\left(k_{i, t-1}\right.$, measured by the WACC), changes in profits ( $E_{i, t-1}$ proxied by EBITDA-to-Sales), the inflation rate in the EMU $\left(P_{t-1}\right)$, and the spread between long-term and short-term yields $\left(S_{t-1}\right)^{10}$.

By including the last two variables, we aim to test changes to the economy and market expectations that are directly linked to the ECB's policies, while still including variables related to the ones Blundell and Roulet use in their analysis. In particular, inflation serves as a proxy for changes in demand and monetary policy. Nonetheless, the relationship between inflation and capital spending is not clear. On the one hand, higher inflationary

\footnotetext{
9 The empirical evidence is also divided: Fama and French (2002) show that companies with higher profits tend to be less leveraged (thus correcting the pecking order model on this issue); whilst Frank and Goyal (2008) show the opposite.

${ }^{10}$ The spread between 10-year weighted average of sovereign bond yields of all EMU countries and 3-month Euribor rate.
} 
pressures may lead the real returns (see Fama and Gibbons, 1982) on projects to be less profitable, but on the other, a rise in the rate of inflation might also indicate higher economic activity. As for the spread between long- and short-term rates, it is used as a proxy of economic conditions. According to Baumeister and Benati (2010), the compression of long-term bond spread may even impact GDP and inflation. Furthermore, this compression tends to indicate a fall in the term premium. The decline in the term premium could be due to lower expectations of either sudden inflation eruptions or lower interest rates in the future because of slower economic activity. In other words, a contracting spread, or the flattening of the yield curve, may correspond to companies reducing capital spending as economic activity deteriorates. Therefore, we would expect a positive relationship between capital expenditure and bond yield spread.

As stated above, our model includes an investment equation (8) and a shareholder yield equation (9) where the variables that may affect the shareholder yield $\left(y_{i, t}\right)$ are explored. Like equation (8), equation (9) also includes the two main ECB policy variables - the cost of debt $\left(i_{t-1}\right)$ and the changes in the ECB's assets $\left(E C B_{t-1}\right)$ - plus another two independent variables: the cost of capital ( $k_{i, t-1}$ measured by WACC) and changes in profits ( $E_{i, t-1}$ proxied now by earnings per sale or EPS of each company). A positive relationship is expected for the former variable (if the cost of retaining a euro to invest relative to the cost of bonds rises, a company is better off repurchasing its shares - and reducing its relative rising cost of capital). Finally, regarding the latter variable, although Blundell and Roulet (2013) use an earnings yield in their model, we decided to use changes in EPS because it isolates the changes in a company's fundamentals by not including the variations in its underlying stock price (which could shift based on changes to liquidity in the markets, supply and demand changes, and more). As for the expected relationship, even though there is no consensus in the literature ${ }^{11}$, we still expect a rise in earnings to lead to higher returns to investors.

\section{Empirical results}

In this section, we first discuss the results from the panel data analysis applied to the leverage, the investment and the shareholder yield regressions. Specifically, we consider two basic panel regression methods: the fixed-effects (FE) method and the random effects (RE) model ${ }^{12}$. To determine the empirical relevance of each of the potential methods for our panel data, we test FE versus RE. We do so by using the Hausman test statistic to analyze the non-correlation between the unobserved effect and the regressors. This test indicates that the fixed effect estimators are more appropriate for all the timeframes in the leverage and the investment regressions. However, in the shareholder yield model, the Hausman test shows that the choice of method (FE or RE) depends on the subsample. Subsequently, we also present the results corresponding to a cross-country and a cross-

\footnotetext{
11 According to Fama and French (2002), more profitable firms tend to have higher dividend payments. But Miller and Modigliani (1961) point out that rising profits do not necessarily lead to a rise in dividend payment - this will depend on other factors such as the payout ratio.

${ }^{12}$ Estimations were also performed by the Arellano-Bond GMM approach, providing similar quantitative results.
} 
sector analysis for the whole period in order to examine whether companies from different countries or industrial sectors react in different ways to the ECB's policies.

In the empirical estimation, we take into account the two substantial economic events which occurred during our sample period: (1) the global economic recession of 2008 and (2) the peak of the European debt crisis in 2011-2012, which may not only have played a substantial role in swaying European companies' decisions, but may also have determined the ECB's monetary policy. Based on the above, we introduce two breakpoints to capture these major events: 2008Q1 (the tipping point for the global economic recession), and 2011Q3 (in order to examine not only whether the European debt crisis may have had an impact on the results, but also whether Mario Draghi's leadership of the ECB had affected them). Therefore, we examined five different time frames: The first covers the sub-period 2000Q2-2008Q1; the second spans from 2008Q2 to 2017Q4; the third ranges from 2000Q2 to 2011Q3; the fourth spans 2011Q4 and 2017Q4; and the last one covers the entire sample period from 2000Q2 to 2017Q4.

\subsection{Panel unit root tests}

A dependent stationary variable cannot be explained using non-stationary variables since the statistical properties of the former (mean, variance, autocorrelation, et cetera) remain constant over time, while those of the latter change. Therefore, to assess the statistical characteristics of our variables, we perform a variety of unit root tests in panel datasets. In particular, we use the Levin-Lin-Chu (2002), Harris-Tzavalis (1999), Breitung (2000), Im-Pesaran-Shin (2003), and Fisher-type (Choi, 2001) tests. The results of these tests ${ }^{13}$ decisively reject the null hypothesis of a unit root for all the variables except for the ECB assets. Therefore, while the rest are found to be stationary in levels, the latter can be treated as first-difference stationary. So, in the different empirical estimations, the variable ECB assets will be transformed into a stationary variable by differencing it.

\subsection{Leverage: Empirical results}

The results regarding the main drivers of the leverage ratio are presented in Table 1. As can be seen, we report the results obtained using the FE model since it is the relevant one in all cases.

\footnotetext{
${ }^{13}$ They are not shown in this paper to save space, but are available from the authors upon request
} 
Table 1: Results of panel analysis for Debt-to-equity

\begin{tabular}{|c|c|c|c|c|c|}
\hline \multicolumn{6}{|c|}{$\begin{array}{c}\text { OLS Estimates of the Effect of the ECB's policies on Leverage } \\
\text { Dependent variable: Debt-to-equity }\end{array}$} \\
\hline & $\begin{array}{l}\text { 2001Q2- } \\
\text { 2011Q3 }\end{array}$ & $\begin{array}{c}\text { 2011Q4- } \\
\text { 2017Q4 }\end{array}$ & $\begin{array}{l}\text { 2001Q2- } \\
\text { 2008Q1 }\end{array}$ & $\begin{array}{c}\text { 2008Q2- } \\
\text { 2017Q4 }\end{array}$ & $\begin{array}{c}\text { 2001Q2- } \\
\text { 2017Q4 }\end{array}$ \\
\hline & (1) & (2) & (3) & (4) & (5) \\
\hline D(ECB Assets (t-1)) & $1.22 * *$ & $8.56 * * *$ & $1.25 * *$ & $65.4 * *$ & $0.1711 * * *$ \\
\hline 3 Mo Yld (t-1) & $-1.174 * * *$ & $-2.495 * *$ & $-0.655^{* * *}$ & $-3.968 * * *$ & $-3.459 * * *$ \\
\hline $\operatorname{EPS}(\mathrm{t}-1)$ & $-2.129 * * *$ & $-1.213 * * *$ & $-1.872 * * *$ & $-2.804 * * *$ & $-2.437 * * *$ \\
\hline WACC & $-7.547 * * *$ & $-4.396 * * *$ & $-6.506 * *$ & $-3.802 * * *$ & $-8.214 * * *$ \\
\hline EBITDA to Revenue (t-1) & $0.028 * * *$ & $\mathbf{0 . 0 5 8} * * *$ & $0.120 * *$ & $0.542 * * *$ & $0.159 * * *$ \\
\hline EU inflation (t-1) & $0.947 * * *$ & $1.768 * * *$ & $7.034 * *$ & $1.086 * * *$ & $4.300 * * *$ \\
\hline Constant & $162.11 * * *$ & $130.81 * * *$ & $149.38 * * *$ & $130.88 * * *$ & $154.77 * * *$ \\
\hline \multicolumn{6}{|c|}{ Statistics } \\
\hline R-squared (overall) & $81.4 \%$ & $82.7 \%$ & $83.3 \%$ & $66.7 \%$ & $75.5 \%$ \\
\hline F-statistic & $49.28 * * *$ & $22.54 * * *$ & $\mathbf{5 1 . 5 0} * * *$ & $54.71 * * *$ & $53.40 * * *$ \\
\hline Total Obs. & 3160 & 1240 & 2044 & 2480 & 4462 \\
\hline Cross sections & 62 & 62 & 62 & 62 & 62 \\
\hline Hausman Test (Chi-Sq Stat.) & $34.91 * * *$ & $47.35 * * *$ & $32.12 * * *$ & $79.21 * * *$ & $36.01 * * *$ \\
\hline RE/FE & FE & FE & FE & FE & FE \\
\hline
\end{tabular}

This table shows the results of estimating an equation for a balanced panel of 62 publicly traded non-financial firms. *, $* *, * * *$ indicate statistical significance at the $10,5 \%$ and $1 \%$ levels respectively.

Results in Table 1 indicate that interest rates and changes to the ECB's balance sheet have a positive and significant impact on companies' leverage. For the entire period (column 5), a one-percentage-point fall in the 3-months Euribor tends to lift the debt-to-equity ratio, on average, by 3.46 percentage points. Moreover, for every 1 trillion euros the ECB adds to its balance sheet via the various LTRO and QE programs, companies are likely to raise their debt ratio, on average, by 0.17 percentage points. A closer examination of the results also reveals that the ECB's policies have a stronger marginal effect on companies' debt-to-equity ratio after 2011Q3 (column 2) and 2008Q1 (column 4). Specifically, the 3-months Euribor coefficients in column 4 (-3.968) and column $2(-2.495)$ are much lower than the coefficients in column $3(-0.655)$ and column 1 (-1.174). As for changes in the ECB's assets, the coefficients are much higher in columns 4 and 2 than in columns 1 and 3. The inflation rate, which is another variable that is indirectly affected by monetary policy, also presents positive and significant coefficients across different time frames. Finally, the fit of the overall regressions is satisfactory as measured by the $\mathrm{R}^{2}$ values, which range from $66.7 \%$ to $83.3 \%$ for the various time samples.

\subsection{Capital spending: Empirical results}

The results corresponding to the investment equation (8) are presented in Table 2. Once again, the FE model is found to be the relevant one in all sample periods under consideration. It can be observed that the ECB's policies (both changes in interest rates 
and balance sheet assets) have a significant and stimulating impact on a company's capital spending across the different time periods under study. In particular, from 2001 to 2017 (column 5) for every 1 trillion euros buildup in the ECB's assets, the capital-spending-tosales ratio rises, on average, by 2.98 percentage points. As for interest rates, a decline of one percentage point in the 3-months Euribor tends to raise the CapEx-to-sales ratio, on average, by 1.5 percentage points.

Table 2: Results of panel analysis for CapEx-to-Sales

\begin{tabular}{||l||c|c||c||c||}
\hline \multicolumn{5}{|c|}{ OLS Estimates of the Effect of the ECB's policies on investments } \\
Dependent variable: CapEx-to-sales
\end{tabular}

This table shows the results of estimating an equation for a balanced panel of 62-64 publicly traded non-financial companies. $* * *, * * *$ indicate statistical significance at the $10,5 \%$ and $1 \%$ levels respectively.

A comparison of the different sub-periods reveals that the ECB's policies related to its interest rates have a stronger marginal impact after 2011Q3. Specifically, based on the results in column 2, for every one-percentage-point decline in the 3-months Euribor, the CapEx-to-sales ratio tends to rise, on average, by 4.19 percentage points. Conversely, before 2011Q4 this coefficient is only 1.68, indicating that changes to the 3-months Euribor rate had a much smaller impact on the CapEx-to-sales ratio before Mario Draghi entered office. The same, however, cannot be said after 2008Q2 (column 4), where the 3months Euribor coefficient is only -0.57 . This result may indicate that the financial crisis may have played an important role in diminishing the correlation between interest rates and capital spending. In other words, it seems that, during 2008-2011 (i.e., between the global recession and the European debt crisis and before Mario Draghi's tenure), interest rates may have had a lesser impact on capital spending than either before or after this period. These results also correspond to the relationship we have highlighted in Section 
3.2: falling interest rates tend to encourage companies to allocate more capital towards investments. For their part the ECB's asset purchase programs seem to have positively affected companies' capital spending; however, the coefficients are not vastly different across the various time frames. This finding suggests that the ECB's policies did not have a marginally stronger impact on companies' capital spending decisions after 2011Q3 or after 2008Q2. Lastly, across the different time periods considered the values of $\mathrm{R}^{2}$ range between $59.9 \%$ and $80.3 \%$. These results indicate that our econometric model may identify notable and interpretable relationships among the economic variables under study.

\subsection{Shareholder yield: Empirical results}

Table 3 presents the results of the panel data analysis for the shareholder yield model. As can be seen, with the exception of the 2011Q4-2017Q4 and the 2088Q2-2017Q4 subperiod (where the tests favour FE), the RE model is found to be the more appropriate for the econometric analysis.

Table 3: Results of panel analysis for Shareholder Yield

\begin{tabular}{|c|c|c|c|c|c|}
\hline \multicolumn{6}{|c|}{$\begin{array}{c}\text { OLS Estimates of the Effect of the ECB's policies on dividends and buybacks } \\
\text { Dependent variable: Shareholder yield }\end{array}$} \\
\hline & $\begin{array}{l}\text { 2000Q2- } \\
\text { 2011Q3 }\end{array}$ & $\begin{array}{c}\text { 2011Q4- } \\
\text { 2017Q4 }\end{array}$ & $\begin{array}{c}\text { 2000Q2- } \\
2008 Q 1\end{array}$ & $\begin{array}{c}\text { 2008Q2- } \\
\text { 2017Q4 }\end{array}$ & $\begin{array}{c}\text { 2001Q2- } \\
\text { 2017Q4 }\end{array}$ \\
\hline & (1) & (2) & (3) & (4) & (5) \\
\hline $\mathrm{D}(\mathrm{ECB}$ Assets (t-1)) & $1.41 * * *$ & $2.40 * *$ & $0.965 * *$ & $2.67 * * *$ & $1.33 * * *$ \\
\hline 3 Mo Yld (t-1) & $-0.839 * *$ & $-2.759 * * *$ & $-0.315 * *$ & $-0.860 * *$ & $-0.912 * * *$ \\
\hline EPS $(\mathrm{t}-1)$ & $0.262 * *$ & $0.485 * * *$ & $0.347 * *$ & $0.095 * *$ & $0.108 * *$ \\
\hline WACC (t-1) & $0.521 * *$ & $0.856 * * *$ & $0.667 * * *$ & $0.493 * * *$ & $0.437 * *$ \\
\hline Constant & $-1.533 * *$ & $-4.051 * * *$ & $-4.645 * *$ & $-0.921 * *$ & $-0.706 * *$ \\
\hline \multicolumn{6}{|c|}{ Statistics } \\
\hline R-squared (overall) & $65.1 \%$ & $62.8 \%$ & $59.1 \%$ & $65.2 \%$ & $73.5 \%$ \\
\hline F statistic & $67.18 * *$ & $22.64 * * *$ & $12.70 *$ & $34.68 * * *$ & $103.52 * * *$ \\
\hline Total Obs. & 3160 & 1240 & 2044 & 2480 & 4463 \\
\hline Cross sections & 62 & 62 & 62 & 62 & 62 \\
\hline Hausman Test (Chi-Sq Stat.) & 4.28 & $12.78 * * *$ & $15.43 * * *$ & 3.92 & 1.93 \\
\hline $\mathrm{RE} / \mathrm{FE}$ & RE & $\mathbf{F E}$ & $\mathbf{F E}$ & RE & RE \\
\hline
\end{tabular}

This table shows the results of estimating an equation for a balanced panel of 62 publicly traded non-financial companies. *,**, *** indicate statistical significance at the $10,5 \%$ and $1 \%$ levels respectively.

The results indicate that changes in the ECB's policies have a positive and significant impact on companies' shareholder yield across the different time samples. In particular, from 2011 to 2017, for every 1 trillion euros the ECB adds to its balance sheet, shareholder yield rises, on average, by 1.33 percentage points (column 5). Moreover, for every one percentage point decline in the 3-months Euribor rate, shareholder yield increases, on average, by 0.912 percentage points. We also find that after 2011Q3 
(column 2) the ECB's policies, mainly related to changes in interest rates (3-months Euribor), seem to have a stronger marginal impact on shareholder yield than before. The results of the regressions are significant according to the F-tests and the $\mathrm{R}^{2}$ values throughout different sample periods. The $\mathrm{R}^{2}$ values range from $59.1 \%$ to $73.5 \%$. Finally, these results also suggest, as indicated in Section 3.2, that lower interest rates do not crowd out dividends or buybacks in favour of investments. This finding implies that the added value for companies of returning capital to shareholders may have been high enough to encourage them to allocate more funds not only to investments but also to shareholder distribution.

\subsection{A Cross-Country Analysis}

In order to analyze how companies from different countries react to ECB policies, we also conducted a cross-country analysis. To this end, we separated the companies in our sample according to their country of origin (based on where their head offices are located): Germany, France, Italy, and Spain. The results of the panel data analysis for the entire period (2000-2017) ${ }^{14}$ show that, for the debt-to-equity ratio, the coefficients for the ECB's assets are positive and significant across the different countries. However, the ECB's balance sheet variable appears to have the strongest stimulating effect on German companies: for every 1 trillion euros the ECB adds to its balance sheet, a German company's debt-to-equity ratio rises, on average, by 4.7 percentage points. Conversely, Italian companies have the lowest coefficient, at 1.51. Moreover, the 3-months Euribor coefficients are all negative and significant. However, Spanish and French companies have the lowest coefficients, at -9.8 and -8.3 respectively. German companies recorded the highest 3-months Euribor coefficients. This result suggests that Spanish and French companies are more sensitive to changes in interest rates than German companies. Regarding the CapEx-to-sales ratio regressions, German companies are the least sensitive to changes in ECB assets or interest rates while Spanish and French companies are the most sensitive to the ECB's policies. Finally, regarding shareholder yields, Italian companies are the least sensitive to changes in the ECB's assets: their coefficient is only 0.267, while the coefficient of Spanish companies is the highest in the sample at 3.06. Conversely, Spanish companies are the least sensitive to changes in interest rates, with a coefficient of -0.452 , while the coefficient of Italian companies is the lowest at -1.437 . These findings indicate that both Italian and Spanish companies are more sensitive to single ECB policies than companies from other countries.

\subsection{A Cross-Industry analysis}

Finally, we also conducted a cross-sector analysis in order to examine whether the effect of ECB policies varies depending on the economic sector. Therefore, we break down the sample into 12 industrial sectors ${ }^{15}$. The results from the panel data regressions for the

\footnotetext{
14 They are not shown in this paper to save space, but are available from the authors upon request.

15 The list of industries is: Basic Materials, Communications, Consumer Discretionary, Consumer Cyclical, Consumer Non-Cyclical, Energy, Industrial, Information Technology, Materials, Technology \& Telecommunications, and Utilities.
} 
entire sample (2000-2017) ${ }^{16}$ for all three models indicate that the ECB's policies (both changes to interest rates and balance sheet) have a stimulating effect across the different industrial sectors, as was the case in previous analyses. Specifically, in the leverage model, the Communications sector has the highest ECB assets coefficient, at 9.3. Moreover, the lowest 3-months Euribor coefficients are for Information Technology, Industrial, and Communications at $-11.927,-11.927$ and -11.187 respectively. Regarding the investment model, Basic Materials have the highest coefficient for changes in the ECB assets, at 2.78, while the Technology \& Telecommunications sector has the lowest 3-months Euribor coefficient at -2.224. Finally, the results for the shareholder yield model show that for the changes in the ECB's assets, the Consumer Cyclical's coefficient is the highest at 4.95; the lowest 3-months Euribor coefficient is for Utilities.

\section{Concluding remarks}

We have analysed the impact of the ECB's monetary policies (both conventional and unconventional) on the capital allocation of leading non-financial firms that operate in the European Economic and Monetary Union, using firm-level data of income statements and balance sheets. In particular, we have examined whether the ECB's monetary policies have encouraged non-financial firms to raise their debt burden, invest more, and boost their shareholder distribution. The main results indicate that the answer to all three questions is affirmative. However, the results also show that these policies seem to have a stronger marginal impact on these companies' decisions not only after the global recession of 2008, but also after late 2011 - when the Euro debt crisis was unfolding and Mario Draghi's appointment as president ushered in dramatic changes in the ECB's policies. We also find that French and Spanish companies appear more sensitive to changes in the ECB's policies on issues of investments and leverage. This finding may have policy implications: The ECB's main asset purchase program (PSPP) allocates its funds based on a country's size rather than its needs. The results suggest that the ECB's policies could boost investments of non-financial firms more efficiently if the bank were to allocate more funds to countries, such as France and Spain, where companies react more strongly to its policies. Finally, one of the ECB's main goals in imposing its stimulative monetary policies was to encourage companies to invest in the economy and thus increase economic growth. As in every empirical analysis, the results must be regarded with caution, since they are based on a set of countries and companies over a certain period and a given econometric methodology. Nonetheless, we show that while the ECB's policies seem to have achieved their aim, they may have also encouraged companies to use the low-interest rate environment to distribute capital to their shareholders. Even though share buybacks and dividends could play a role in boosting economic activity ${ }^{17}$, their stimulative impact on the economy is indirect and unclear.

\footnotetext{
${ }^{16}$ They are not shown in this paper to save space, but are available from the authors upon request.

17 The excess capital shareholders receive could be used to reallocate funds to firms that require capital for investment. Shareholders could use the funds to increase their spending, which, in turn, could also boost economic activity. Nonetheless, not all shareholders live in the EMU, and so this spending may occur abroad. Also, shareholders could decide to invest in companies outside the EMU. These points only show that it is unclear how shareholder distribution affects the economy.
} 


\section{Acknowledgments:}

The authors wish to thank an anonymous referee and the editor for their helpful comments and suggestions on a previous draft of this article, which have enabled us to introduce substantial improvements.

\section{Funding}

This work was supported by the Spanish Ministry of Economy and Competitiveness [grant ECO2016-76203-C2-2-P]. 


\section{References:}

Baumeister, C., and L. Benati. 2010. "Unconventional Monetary Policy and the Great Recession - Estimating the Impact of a Compression in the Yield Spread at the Zero Lower Bound”. International Journal of Central Banking 9 (2): 165-212.

Barry B.C., S.C. Mann, V.T. Mihov, and R. Mauricio. 2008. "Corporate Debt Issuance and the Historical Level of Interest Rates". Financial Management 37:413-430.

Bernhardt, D., A. Douglas, and F. Robertson. 2002, “Testing dividend signaling models". Journal of Empirical Finance 12 (1): 77-98.

Bernanke, B., and V. Reinhart. 2004. "Conducting Monetary Policy at Very Low ShortTerm Interest Rates". American Economic Review 94: 85-90.

Blundell-Wignall, A., and C. Roulet. 2013. "Long term investment, the cost of capital and the dividend and buyback puzzle". OECD Journal: Financial Market Trends 104.

Black, F., and M. Scholes. 1974. "The effects of dividend yield and dividend policy on common stock prices and returns". Journal of Financial Economics 1 (1): 1-22.

Breitung, J. 2000. "The local power of some unit root tests for panel data". In Advances in Econometrics, Volume 15: Nonstationary Panels, Panel Cointegration, and Dynamic Panels, edited by B. H. Baltagi, T. B. Fomby and R. C. Hill. B. H. Baltagi, 161-177. Emerald Group Publishing Limited.

Choi, I. 2001. "Unit root tests for panel data". Journal of International Money and Finance 20: 249-272.

Darracq-Paries. M., and R.A. De Santis. 2015. “A non-standard monetary policy shock: The ECB's 3-year LTROs and the shift in credit supply". Journal of International Money and Finance $54(\mathrm{C}): 1-34$.

Fama, E.F., and M.R. Gibbons. 1982. "Inflation, real returns and capital investment". Journal of Monetary Economics 9 (3): 297-323.

Fama, E.F., and K.R. French. 2002. "Testing Trade-Off and Pecking Order Predictions about Dividends and Debt". The Review of Financial Studies 15 (1): 1-33.

Fairchild, J.R. 2006. "When Do Share Repurchases Increase Shareholder Wealth?" Journal of Applied Finance, Vol. 16 (1).

Fernandez-Rodriguez, F., S. Sosvilla Rivero, and J. Andrada-Felix, 1999. "Exchange-rate forecasts with simultaneous nearest-neighbour methods: evidence from the EMS". International Journal of Forecasting 15: 383-392.

Frank, M.Z., and V.K. Goyal. 2008. "Profits and Capital Structure". Paper presented at the annual meeting for the American Financial Association, San Francisco, January 3-5. Gambacorta, L., B. Hofmann, and G. Peersman. 2014. "The effectiveness of unconventional monetary policy at the zero-lower bound: a cross-country analysis". Journal of Money, Credit and Banking 46: 615-642.

Giannone, D., M. Lenza, H. Pill, and L. Reichlin. 2012. "The ECB and the interbank market". Economic Journal 122: 467-486.

Gup, B.E., and D. Nam. 2001. "Stock Buybacks, Corporate performance and Eva". Journal of Applied Corporate Finance 14: 99-110.

Hansen, A. 1939. "Economic progress and declining population growth". American Economic Review 29: 1-15. 
Harris, R. D. F., and E. Tzavalis. 1999. "Inference for unit roots in dynamic panels where the time dimension is fixed". Journal of Econometrics 91: 201-226.

Hussainey, K., C.O, Mgbame, and A.M. Chijoke-Mgbame. 2011. "Dividend policy and share price volatility: UK evidence". The Journal of Risk Finance 12 (1): 57-68.

King, G., J. Honaker, A. Joseph, and K. Scheve. 2001. "Analyzing incomplete political science data: an alternative algorithm for multiple imputation". American Political Science Review 95: 49-69.

Kraus, A., and R. Litzenberger. 1973. "A State Preference Model of Optimal Financial Leverage". The Journal of Finance 28: 911-922.

Krugman, P. R. 1998. "It's baaack: Japan's slump and the return of the liquidity trap. Brookings Papers on Economic Activity 29:137-205.

Krugman, P. R., and G.B. Eggertsson. 2012. "Debt, Deleveraging, and the Liquidity Trap: A Fisher-Minsky-Koo Approach”. The Quarterly Journal of Economics 127: 1469-1513 Kühnhausen, F., and H.W. Stieber. 2014. "Determinants of capital structure in nonfinancial companies". Munich Discussion Paper No. 2014-38, Department of Economics, University of Munich, Munich.

Lenza, M., H. Pill., and L. Reichlin, 2010. "Monetary policy in exceptional times". Economic Policy 62: 295-339.

Levin, A., C.-F. Lin, and C.-S. J. Chu. 2002. "Unit root tests in panel data: Asymptotic and finite-sample properties". Journal of Econometrics 108:1-24.

Merton, R. 1974. "On the Pricing of Corporate Debt: The Risk Structure of Interest Rates". The Journal of Finance 29(2): 449-470.

Miller, M., and F. Modigliani. 1961. "Dividend Policy, Growth, and the Valuation of Shares". The Journal of Business 34(4): 411-433.

Modigliani, F., and M. Miller. 1958. "The Cost of Capital, Corporation Finance and the Theory of Investment”. American Economic Review 53:261-297

Myers, S. C. 198). “The Capital Structure Puzzle”. The Journal of Finance 39: 574-592

Rajan, R.G., and L. Zingales. 1995. "What do I know about capital structure? Some evidence from international data". Journal of Finance 50: 1421-1460.

Summers, L. 2013. "Why stagnation might prove to be the new normal". Financial Times, December 15.

Wu, J. C., and F.D. Xia. 2016. "Measuring the macroeconomic impact of monetary policy at the zero lower bound". Journal of Money, Credit and Banking 48: 253-291. 
Appendix A: Description of variables and data sources

\begin{tabular}{|c|c|c|}
\hline Variable & Description & Source \\
\hline \multicolumn{3}{|c|}{ Dependent variables } \\
\hline Debt-to-equity & Non-Financial Corporate debt to equity ratio & Bloomberg \\
\hline Shareholder yield & $\begin{array}{l}\text { Returns to investors per share - including buybacks, } \\
\text { dividends and deleverage per company }\end{array}$ & Bloomberg \\
\hline CapEx-to-sales & Capital spending per revenue of a company & Bloomberg \\
\hline \multicolumn{3}{|c|}{ Monetary policy variables } \\
\hline ECB total assets & $\begin{array}{c}\begin{array}{c}\text { Total assets on the ECB's balance sheet (in trillions } \\
\text { of euros) }\end{array} \\
\end{array}$ & FRED \\
\hline 3-months Euribor rate & Weighted average rate of a 3-months libor in euros & FRED \\
\hline \multicolumn{3}{|c|}{ Control variables } \\
\hline EBITDA-to-revenue & EBITDA-to-revenue of a company & Bloomberg \\
\hline WACC & Weighted Average Cost of capital of a company & Bloomberg \\
\hline $\begin{array}{l}\text { Spread between } 10 \text { year and } 3 \\
\text { months Euribor }\end{array}$ & $\begin{array}{l}\text { Gap between weighted average yield of a } 10 \text {-year of } \\
\text { EMU governments note and } 3 \text {-months libor in euros }\end{array}$ & Eurostat and Fred \\
\hline 10-year EU government bond & $\begin{array}{l}\text { Weighted average yield of a 10-year of EMU } \\
\text { governments note }\end{array}$ & Eurostat \\
\hline Total Debt & $\begin{array}{l}\text { The total long term and short term of a company as } \\
\text { recorded on its balance sheet }\end{array}$ & Bloomberg \\
\hline EPS growth & $\begin{array}{c}\text { Quarter-on-quarter rate of growth of earnings per } \\
\text { share }\end{array}$ & Eurostat \\
\hline Inflation & $\begin{array}{l}\text { Year-on-year rate of growth of Harmonized Index of } \\
\text { Consumer Price in EMU (HICP) }\end{array}$ & Eurostat \\
\hline
\end{tabular}

